\title{
UK seeks to appease food safety critics
}

[PARIS] The British government last week announced plans to set up an independent food safety council to advise it on food policy, after conceding that it is no longer trusted by the public on such issues in the wake of the 'mad cow' crisis.

The proposal has been welcomed by farmers' groups as a way of addressing public concern about safety. But consumer groups and opposition parties have criticized the government for stopping short of setting up a food agency independent from the Ministry of Agriculture, Fisheries and Food.

The council, whose creation will depend on the Conservatives winning the impending general election, would have 20 expert and lay members and would meet four times a year. It would be free to comment on all aspects of government food policy, such as safety, quality and labelling. The conclusions of the council's meetings would be made public, and it would submit an annual report to parliament.

The government has also announced that it plans to appoint a Food Safety Adviser, a Medical Officer, to head the council.

The part-time adviser would be an eminent scientist who would answer directly to ministers, but who would in principle be free to criticize government policy. He or she would have an important role in dealing with senior official similar in status to its Chief

the media and appearing before parliamentary select committees to explain the council's position on government policy.

The plans were unveiled last week by the agriculture minister, Douglas Hogg, and the health secretary, Stephen Dorrell. Hogg said the council would leave executive control of food policy to government but would act as a watchdog free to "speak out robustly" on government policy. "We are making a rod for our own backs," he said.

Hogg conceded that the public no longer believes what it is told by the government on food safety issues, perceiving it to be "too closely related with the producing industry". He said he hoped that the council would "greatly enhance people's perceptions of the independence of the advice that government is receiving".

The proposals have been cautiously welcomed by farmers' groups. "This model could be made to work if it has the right people with autonomy," says Ian Gardiner, director of policy at the National Farmers' Union.

But Sue Todd, an official at the UK Consumers' Association, says that, while the association welcomes the government's recognition "that there is a problem", the proposals fall far short of what is needed to restore consumer confidence in government decisionmaking after the crisis over bovine spongi-

\section{AIDS 'cure' scientists go to top for funds}

[CAPE TOWN] Three scientists at the University of Pretoria, who claim to have found a cure for AIDS, last month appealed to the South African cabinet for R3.7 million (U\$800,000) to continue their research.

But their use of such an unconventional channel has focused attention on both the product itself, patented as Virodene $P 058$, and its clinical trials, which are alleged to have been carried out without going through normal approval procedures.

The interview with cabinet members was arranged by the health minister, Nkosazana Zuma, who appeared reluctant to take personal responsibility for granting the scientists' request for funding from her department. The department has $\mathrm{R40}$ million available, from the European Union and South Africa's own Reconstruction and Development Programme funds, for research and other activities aimed at combating sexually transmitted diseases.

The cabinet gave a standing ovation to the three researchers - Dirk du Plessis and Kallie Landauer, both cardiothoracic surgeons, and Olga Visser, a technician. The deputy president, Thabo Mbeki, said their request would be considered. But the following day the University of Pretoria announced that a committee had been set up to investigate a "deviation from the university's established research practices" by the three researchers.

It is alleged that phase one clinical trials were carried out on 12 patients without the consent of either the university's ethics committee or the Medicines Control Council, the authority that considers applications to conduct drugs trials.

Peter Folb, chairman of the council and professor of pharmacology at the University of Cape Town, confirms that it had not previously reviewed an application for testing Virodene P058, but that an application had been rejected by the University of Pretoria's ethics committee.

The council has now started its own investigation into the pharmacological properties of the drug. This is due to be completed this week, as is the university's inquiry. The drug is said to contain a compound that can penetrate lymphocytes and inhibit viral replication because of its low molecular weight and its composition. There has been speculation that Zuma herself granted permission for clinical trials, bypassing both the university and the national authorities. But she has been unavailable for comment. MichaelCherry

\section{IMAGE UNAVAILABLE FOR COPYRIGHT REASONS}

Hogg: Food safety council would be free to "speak out robustly" on government policy.

form encephalopathy (BSE).

The council would be "just another advisory body", claims Todd. She argues that its creation fails to address the fundamental problem: the conflict arising from the fact that the agriculture ministry is responsible for both promoting the interests of industry and protecting consumers. She says that in practice consumer interests tend to lose out.

Todd argues that the government department that promotes agriculture and food production needs to be separate from the regulatorybody, as is being proposed at the European Commission (see Nature 385, 285; 1996). This separation would encourage a more open debate "about how decisions are made and the evidence on which they are based", she says.

Similarly, the opposition Labour party, which has promised to set up an independent food agency with regulatory powers if it wins the election, says the council would lack "the powers or resources to make a major impact".

The fact that the government has stated explicitly that a major role of the new adviser would be to handle the media and general public has also raised concern that the post may have as much to do with public relations as public safety.

Meanwhile, a report by the French senate last week called for the setting up of a national food safety agency separate from the French ministry of agriculture, as well as the creation of an early-warning body similar to the US Centers for Disease Control in Atlanta.

The author of the French report, Claude Huriet (Meurthe-et-Moselle), complained of glaring gaps in France's institutional capacity to manage public- health risks, and deplored the low funding for such activities compared with that in the United States.

An independent European Union food agency or even a world food agency may be needed, says Gardiner. He argues that the gradual liberalization of trade in food and agriculture is likely to see an increase in disputes such as those about genetically modified organisms, or the use of hormones to boost beef and milk production. DeclanButter 